\title{
Development of techno-pedagogy approach learning model to improve digital literation of UPN "Veteran" Jawa Timur's students
}

\author{
Endang Sholihatin, Ika Korika Swasti, Sukirmiyadi, Kinanti Resmi Hayati* \\ UPN “Veteran” Jawa Timur, Surabaya, Indonesia \\ endang.sholihatin.ak@upnjatim.ac.id, kinantihayati.ti@upnjatim.ac.id \\ *Corresponding Author: kinantihayati.ti@upnjatim.ac.id | Phone Number: +6283840570015
}

\section{ARTICLE INFO \\ Received: 29-05-2021 \\ Received in revised: 26-06-2021 \\ Accepted: 22-07-2021 \\ Available online: 30-8-2021}

\section{KEYWORDS}

Techno-pedagogy approach;

Digital literacy;

Students; Lecturers;

\begin{abstract}
A B S T R A C T
The study objectives were 1) to describe the level of digital literacy of UPN "Veteran" Jawa Timur's students; and 2) Developing a techno-pedagogy approach to improve digital literacy of UPN "Veteran" Jawa Timur's students. This research innovation is developing of a techno-pedagogy approach model and arranging a techno-pedagogy approach to improve students' digital literacy. This innovation is based on the idea of a pedagogical model which is an important aspect in achieving learning goals in the world of education. In the first study objective, quantitative methods are used, the second research objective uses qualitative methods. Research location at UPN "Veteran" Jawa Timur. This option is to provide insight, knowledge, and solutions to integrated pedagogical problems in learning amid the Covid-19 pandemic. Data were collected from questionnaires and in-depth interviews. Among the data needed are online skills; motivation; online video/audio; internet discussion; supporting elements; ict abilities; blended learning models; teaching contents; frequencies of face-to-face meeting; regulation; culture.
\end{abstract}

\section{INTRODUCTION}

The world education system is currently faced with the challenge of using information and communication technology (ICT) that is integrated with the education system. The application of technology to improve teaching and learning for students directs learning about technology that can be applied to future learning in a caring, intelligent, sensible, and responsible manner. The Minister of Education and Culture made a policy of "Kampus Merdeka" which required provision for students to seek new experiences. Departing from this problem, it was necessary to develop a learning model. This is part of the development of education which demands a number of instruments that can be used by students and lecturers in the knowledge transfer process for the $3^{\text {rd }}$ millennium in the $21^{\text {st }}$ century. The application of technology to improve teaching and learning for students directs learning about technology that can be applied to future learning in full caring, intelligent, sensible, and responsible manner. The implication of using ICT in learning demands a strategic role for lecturers/teachers (Arezlvarez, 2006).

The School of Education at Lethbridge University in Canada creates innovative learning environments for stud- ents to explore technology and design creative approaches to integrating technology into future classrooms. Technology is used to teach students about technology; integration is thus practical as well as theoretical in its approach (Clifford, Friesen, and Lock 2004). Through metacognitive teaching think about teaching and plan teaching to meet the specific needs of students. Metacognitive teaching is not only including teacher awareness of the sources and characteristics of student misunderstandings but also monitoring and evaluation of the extent to which important misconceptions have changed productively (Hartman 2001). Creating innovative classroom and online learning environments are a challenge in the midst of advances in ICT. Through this approach, students realize that meaningful teaching with technology does not require lecturers to become technology or computer experts.

The study on the techno-pedagogical approach to improve digital literacy of UPN "Veteran" East Java students is important to advance better and more creative teaching and learning processes supported by ICT. Even though there have been preliminary studies in other countries, 
considering that the educational process in the transfer of knowledge is strongly influenced by infrastructure, skills, educational culture, government policies and so on, this research has great benefits. One aspect needs to be underlined as research results (Castellano, 2010; Cebrián, 2003) have found that the use of ICT in the teaching and learning process is beneficial and when teachers are trained to use ICT, it is possible to support the process. In its development, there are so many technological resources available to support the educational process, but not all lecturers and students use them to support the learning process. This is due to a lack of knowledge to integrate developments into the classroom, and a lack of training in the pedagogical use of technology. From this description, the objectives of this research are: (a) To describe the digital literacy level of UPN "Veteran" East Java students; (b) to develop a techno-pedagogy approach to improving digital literacy of UPN "Veteran" East Java students.

\section{LITERATURE REVIEW}

\section{Techno-pedagogy Approach}

The growth of information and communication technology (ICT) has driven various transformations in life and fostered dynamism in various circles including education. As stated by Beaudin and Hadden (2004) that technopedagogical skills help students for further development, achievement of learning outcomes and designing classbased resources through the use of ICT by teachers. Therefore, the techno-pedagogical method is an important component. The need for individuals to equip themselves with a wide range of technological skills has been emphasized widely, because mastering such skills enables them to use, manipulate and disseminate information in a sophisticated world. There is a Framework for Technological Pedagogical-content Knowledge as stated by Koehler \& Mishra (2009) as follows:

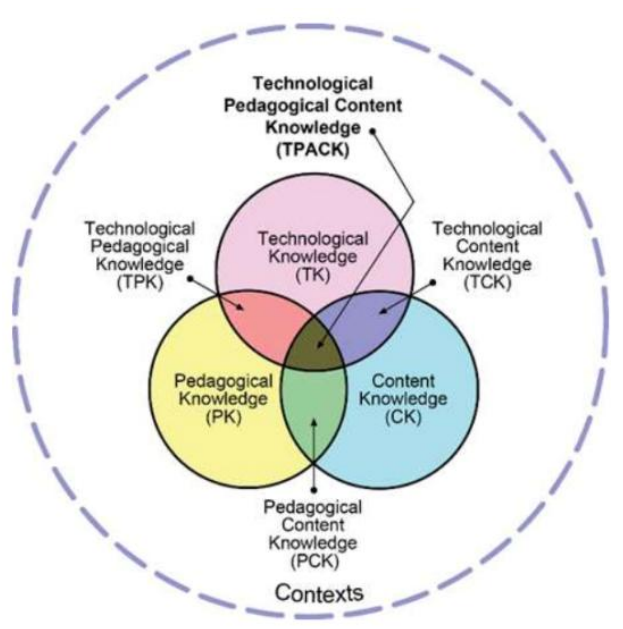

Figure 1.Technological Pedagogical-Content Knowledge source: Koehler \& Mishra (2009).

Based on the picture above, in the framework of Technological Pedagogical-content Knowledge, there are three main knowledge in the educational process, namely Technology Knowledge, Content Knowledge and Pedagogical Knowledge. These three points should not be looked at in isolation, but they reflect the complex interplay of all the knowledge essential for teaching with technology, which is positioned at the heart of this framework.

Furthermore Koehler and Mishra (2005) added in their study that better teaching not only adds technology but the introduction of technology leads to new conceptual representations and needs to develop sensitivity to dynamics, transactional relationships between technology, pedagogy, content and knowledge. The real interest underlying students' need for technological skills is the lifelong learning it promotes; provides freedom for learners to shape their own learning paths through collaboration and new technology (Attwell, 2007). Information, communication, knowledge and technology in the present era have produced different types of learners, compared to the traditional era. Techno-pedagogical knowledge is carried out based on improving the effectiveness of the learning and teaching process for professional development with technology integration (Archambault \& Crippen, 2009).

Pedro (2006) states that today's student learner is a group that grows surrounded by digital media. He called them "new millennial learners" regarding attention span, multi-tasking and nonlinear ways of retrieving information. Therefore, teaching educators to teach the new millennium need to attract and retain students' attention in various ways during the teaching and learning process (Ala-Mutka et al., 2008). This can be more challenging because students learn in different ways and educators need to have a broad pedagogical scope to fulfill meaningful learning for every type of learner to enter the industrial revolution 4.0.

\section{Digital Literacy for Dtigal Native Generation}

The development of ICT requires each individual to follow the development of information for his/her needs, including for the educational process. In the rapid development of ICT, it shifted from print media to digital media and gave birth to a new culture in society. The new culture is a digital culture with ICT infrastructure (internet) as a platform for information dissemination. Starting from this phenomenon, digital culture has developed (digital natives), especially with the rapid advancement of smartphones.

Internet users (digital natives) aged 16-24 years (2020) spend an average of time using the internet as follows. 


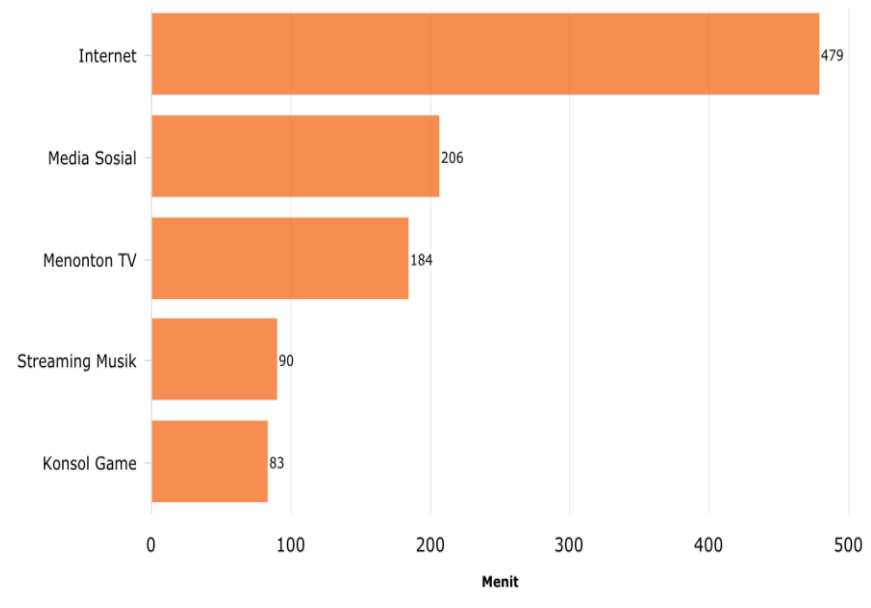

Figure 2. Time spent using the Internet at the age of 16-24, 2020.

Source: Hootsuite, We Are Social, 2020 in

https://databoks.katadata.co.id/datapublish/2020/02/26/indonesiahabiskan-hampir-8-jam-untuk-berinternetz

Based on the data above, Indonesians spend around 8 hours per day utilizing the internet. This shows that the interest in using the internet is quite high. In addition, the existence of the internet is considered quite important and is part of their daily activities.

\section{Learning Model Techno-Pedagogy Approach To Improve Student Digital Literacy}

The form of the model in this research is an image model of a techno-pedagogy approach design in the era of the industrial revolution 4.0 to develop digital literacy of management students of FEB UPN "Veteran" Jawa Timur. Developing a techno-pedagogy approach to developing digital literacy effectively into teaching needs to be developed technology integration planning (TIP) that guides making good decisions about integrating technology into teaching (Roblyer \& Doering, 2013), with the aim of producing successful teaching. and learning outcomes. This model goes beyond three distinct phases for technology integration into teaching, namely (a) Needs analysis, (b) Planning for integration and (c) Post-instruction analysis and revision

\section{METHODS}

The study on a techno-pedagogical approach model to improve digital literacy of UPN "Veteran" Jawa Timur students, using a mixed qualitative and quantitative research approach. The first research aim used quantitative methods, the second research aim used qualitative methods. Qualitative research for finding the depth of data and quantitative research for surveys on UPN "Veteran" Jawa Timur students. Research location at FEB UPN "Veteran" Jawa Timur. This choice is based on the availability of adequate digital infrastructure as well as students and lecturers (leaders in the FEB environment), especially Management who support each other. The research analysis unit is a techno-pedagogical approach to improve digital literacy of UPN "Veteran" jawa Timur's students at the individual and policy level. Sources of research data for students, lecturers, leaders at FEB UPN "Veteran" Jawa Timur and administrative staff. Based on the research objectives, the techno-pedagogy approach research model is to improve digital literacy of UPN" Veteran" jawa Timur's students is applied research with case studies.

\section{RESULTS AND DISCUSSIONS \\ Digital Literacy Level for UPN "Veteran" Jawa Timur's Students}

There are five indicators to determine the literacy level of UPN V East Java students referring to DigComp 2.0: The Digital Competence Framework for Citizens, which are as follows.

a) Information and Data Literacy

It should be noted that in terms of information literacy and data, students must be able to search for digital information or data properly according to their needs. Furthermore, students must also be critical to the data or information obtained. In other words, students must be able to evaluate the data or information. That way, students are also expected to be able to store and use digital information or data.

\section{b) The existence of Communication and Collaboration}

Humans are social creatures that cannot be separated from interactions with other people. In interacting with other students, students create communication and collaboration. In communicating and collaborating, students are very close to the use of digital technology. Students as good citizens must be wise in using digital services to participate in the social environment. The use of digital technology to share data and information must be done by referring to precise and accurate references. In addition, students must also prioritize good norms or ethics as well as knowledge when using digital technology to interact or collaborate with others. The thing to remember is that in a social environment there are various cultures and generations. In addition, there is also a need for digital identity management that can protect the reputation of students themselves.

\section{c) Creating Digital Contents}

Students must be able to express themselves through digital means and develop digital content into new, original, and relevant knowledge. Next, students must also learn about copyright and licensing regarding information, data, and digital content.

d) Security

It is important to know that digital devices, content, personal data, and student privacy must be protected. In 
using digital technology there is an impact on the students themselves. Therefore, physical and psychological health conditions must be considered in social interactions in the digital era.

e) Problem solving

In today's digital era, students are required to be able to identify needs and problems, and solve conceptual problems in the digital environment. In addition, it is also required to be able to use digital devices to innovate processes and products to keep them up-to-date with digital evolution. Another thing that must be done is to identify any digital competency gaps. Thus, if students' digital competencies are known, they need to be improved or updated. So that the student's digital competence can be an opportunity to develop himself.

Development of a Techno-Pedagogy Approach Learning Model to improve digital literacy of UPN "Veteran" Jawa Timur's students

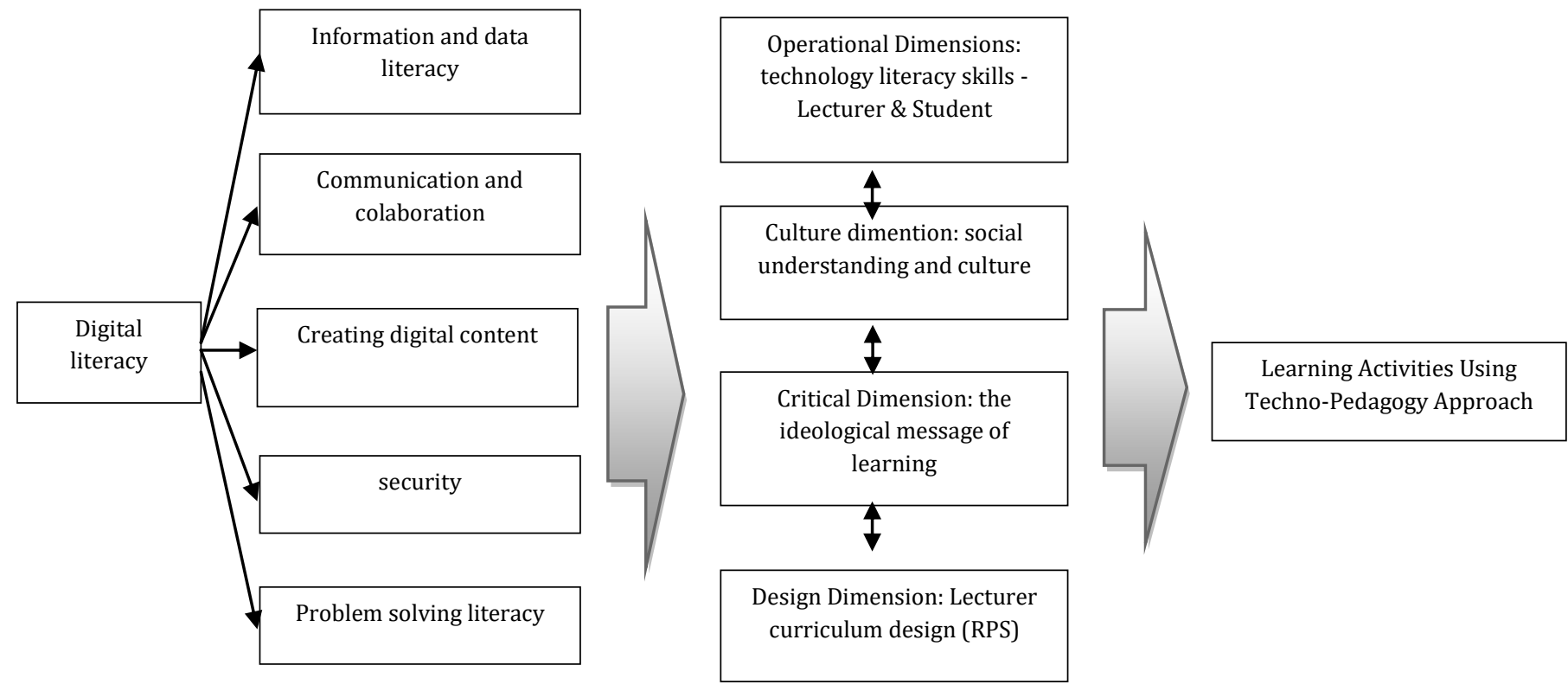

Figure 3. Techno-Literacy Model Development

Teachers who worked with computer technology will not make teachers (lecturers) helpless. The design fulcrum of the technology literacy model offers a means of achieving balance and fairness in the text choices, assignments, learning experiences and assessment modes, it offers teachers big opportunity to demonstrate their creativity and ingenuity as designers. The use of ICT in learning can be one place where not only students are active learners, but also lecturers function as curriculum makers or innovators in their own classrooms. Thus, the design idea is expanded to cover the entire process of knowledge construction, representation and assessment as an integral part of the lecturers/teaching professional. The TechnoPedagogy Approach process must focus on student activities. The techno-pedagogy approach reaffirms the role of the teacher in a student-centered digital environment.

\section{CONCLUSIONS}

Based on the data presentation and data analysis above, it can be concluded that (a) the digital literacy level of UPN "Veteran" Jawa Timur's students is relatively good. This can be seen from the results of five aspects (a) Information and data literacy, (b) Communication and collaboration, (c) Digital content (d) creation, (e) Security, (f) Problem solving aspects $a$ and $b$ are strong but aspects $c, d, e$, and $f$ are still not enough.; (b) Development of a technopedagogy approach: a techno-pedagogy approach with face-to-face learning collaboration and the use of ICT can strengthen learning outcomes by strengthening four aspects (a) operational dimensions: technological literacy skills - lecturers \& students, (b) cultural dimensions: social and cultural understanding; (c) critical dimension: the ideological message of learning; (d) design dimension: lecturer curriculum design (RPS). The techno-pedagogy approach actually provides a multi-learning experience (face-to-face and ICT) that is full, creative, and full of technological literacy practices by lecturers. Greater opportunities arise to explore new teaching paradigms that are compatible with the digital world. In a climate of mutual support and collegial sharing, educators must be able to engage in philosophical and educational debates, devise ways of ensuring that participation is inclusive and fun, and reflect on strategies that promote critical and creative use of technology. Adopting the fourth dimension of design in teaching practice reaffirms the important role of teachers in the teaching and learning process. Professional development programs in computer literacy should be expanded to include the design of effective teaching/learning environments. 


\section{Acknowledgement}

The authors would like to thanks LPPM UPN 'Veteran” Jawa Timur and all of the correspondents.

\section{Author's Contributions}

All authors discussed the results and contributed to from the start to final manuscript.

\section{Conflict of Interest}

The authors declare that they have no competing interests.

\section{REFERENCES}

Álvarez, M. (2006). Delimitaciones previas a la formación para el uso de las TIC en la enseñanza universitaria.

http://openaccess.uoc.edu/webapps/o2/

bitstream/10609/1666/1/alvarez_Guasch_Espasa_CIDUI_06_pap er.pdf

Attwell, G. (2007). Personal Learning Environments - the future of eLearning? E-Learning Papers, 2(1). Retreived 5th July 2013 from http://www.elearningpapers.eu/.

Archambault, L., \& Crippen, K. (2009). Examining TPACK among K12 online distance educators in the United States. Contemporary Issues in Technology and Teacher Education, 9(1), 71-88. Retrieved from http://www.citejournal. org/vol9/iss1/general/article2.cfm

Ala-Mutka, K., Bacigalupo, M., Kluzer, S., Pascu, C., Punie, Y., and Redecker, C. (2008). Learning 2.0: The Impact of Web 2.0 Innovation on Education and Training in Europe: Report on a validation and policy options workshop organised by IPTS. Seville, 29- 30 October 2008. Retrieved May 2nd 2013 from http://ftp.jrc.es/EURdoc/JRC50704.

Beaudin, L., \& Hadden, C. (2004). Developing techno pedagogical skills in preservice teachers. In Proceedings of World Conference on E-Learning in Corporate, Government, Healthcare, and Higher Education 2004, 492-498. Norfolk,VA: Association for the Advancement of Computing in Education. Retrieved from http://www.innovateonline.info / index.php?view= article\&id=36.
Boyd, D. (2014). It's Complicated: The Social Lives of Networked Teens. New Haven, Connecticut: Yale University Press. pp. 177-194

Castellano, H. (2010). Integración de la tecnología educativa en el aula: Enseñando con las TIC [Integration of educational technology in the classroom]. Buenos Aires, Argentina: Cenage Learning.

Cebrián, M. (2003). Enseñanza virtual para la innovación universitaria [Virtual teaching for university innovation]. Madrid, Spain: Ediciones Narcea.

Ghaith, G. (2010). An exploratory study of the achievement of the twenty-first century skills in higher education. Education \& Training, 52 (6/7), 489-498.

Ku, D.T., \& Soulier, J.S. (2009). Effects of learning goals on learning performance of field-dependent and field-independent late adolescent in a hypertext environment. Adolescence, 44, 651-664.

Koehler, M. J., \& Mishra, P. (2005). What Happens When Teachers Design Educational Technology? The Development of Technological Pedagogical Content Knowledge. Journal of Educational Computing Research, 32(2), 131-152.

Moleong, Lexy J. (2006). Metodologi Penelitian Kualitatif. Bandung: PT. Remaja Rosda Karya.

Miles, B.B., dan A.M. Huberman. (1992). Analisa Data Kualitatif. UI Press Jakarta.

Pedro, F. (2006). The new Millennium Learners: Challenging our Views on ICT and Learning: OECD-CERI http://www.oecd.org/dataoecd/1/1/38358359.pdf

Roblyer, M. D. \& Doering, A. H. (2013). Integrating Educational Technology into Teaching (6th ed.). United States of America: Pearson. 